\title{
Plakkmodifikáció a 21. században - az első magyar tapasztalatok az intravascularis lithoplasticával
}

\author{
Németh Balázs Tamás dr. - Édes István Ferenc dr. - Szilveszter Bálint dr. \\ Nowotta Fanni dr. - Becker Dávid dr. - Merkely Béla dr.
}

Semmelweis Egyetem, Általános Orvostudományi Kar, Városmajori Szív- és Érgyógyászati Klinika, Budapest

\begin{abstract}
A nagy mésztartalmú plakkok által okozott szúkületek percutan intervenciója az esetek egy részében a jelenleg széles körben elérhető megoldások alkalmazásával technikailag nem kivitelezhető. A procedurális sikertelenség vezető oka a meszes laesiók kalciumtartalom miatti fokozott ellenállása a ballonos dilatációkkal szemben, mely lehetetlenné teszi a szükséges sztentek levezetését is. Az ilyen laesiók mésztartalmának csökkentését célzó hagyományos plakkmodifikációs eljárások - mint a rotablatio, a vágó- és ultranagy nyomású ballonok - sem jelentenek megoldást minden esetben, különösen az érfal átmérőjének legalább 50\%-át elérő, akár körkörösen jelen lévő meszesedés fennállása esetén. A közelmúltban éppen ezen laesiók mésztartalmának feltördelésére, így a sztentek deponálásának elősegítésére kifejlesztett módszert a szakirodalom intravascularis lithoplastica néven említi. A jelen közleményben a Klinikánkon eddig 4 beteg rendkívül meszes laesióinak jó angiológiai eredményű ellátása során az eszközzel szerzett tapasztalatokat foglaljuk össze. A végeredményt tekintve az intravascularis lithoplastica ígéretes új intervenciós lehetőség a masszívan meszes coronarialaesiók ellátására.
\end{abstract}

Orv Hetil. 2021 ; 162(2): 69-73.

Kulcsszavak: vascularis calcificatio, koszorúér-szúkület, gyógyszerkibocsátó sztentek, angioplastica, OCT, IVUS

\section{Plaque modification in the 21st century - the first Hungarian experiences with intravascular lithoplasty}

Percutaneous intervention of stenoses caused by highly calcified plaques utilizing the currently widely available methods is not possible due to technical difficulties in several cases. Increased resistance of calcified plaques against balloon dilation due to their calcium content plays a leading role in procedural failure, as stent crossing becomes impossible as well. Classical methods of plaque modification for debulking the calcification of such lesions - such as rotablation, cutting and ultra-high pressure non-compliant balloons - do not resolve this issue, especially when calcification exceeds $50 \%$ of the vessel diameter. A new method, referred to as intravascular lithoplasty in the literature, has recently been developed to break the calcium and thus promote stent deployment in such lesions. In our current work, we summarize the experience gathered with this method during the treatment of extremely calcified lesions of 4 patients with good angiographic result. As a conclusion, intravascular lithoplasty is a promising new interventional method in the treatment of massively calcified coronary lesions.

Keywords: vascular calcification, coronary stenosis, drug-eluting stents, angioplasty, OCT, IVUS

Németh BT, Édes IF, Szilveszter B, Nowotta F, Becker D, Merkely B. [Plaque modification in the 21 st century - the first Hungarian experiences with intravascular lithoplasty]. Orv Hetil. 2021; 162(2): 69-73.

(Beérkezett: 2020. június 24.; elfogadva: 2020. július 24.)

\section{Rövidítések}

atm = atmoszféra (nyomás); CT = (computed tomography) számítógépes tomográfia; IVL = (intravascular coronary lithoplasty) intravascularis coronaria-lithoplastica; IVUS $=($ intravascular ult- rasound) intravascularis ultrahangvizsgálat; $\mathrm{MCAE}=$ ( major cardiovascular adverse events) nagyobb cardiovascularis adverz események; $\mathrm{NC}=$ (non-compliant) nem táguló; $\mathrm{OCT}=$ (optical coherence tomography) optikaikoherencia-tomográfia 
Nagy mésztartalmú plakk jelenléte a koszorúérrendszerben jelentősen befolyásolja az esetlegesen szükséges intervenció sikerességét több tényező által is: nehezíti a sztentnek a laesión való átjuttatását, miközben az eszköz gyógyszertartalmú polimerbevonata is sérülhet, továbbá akadályozza a sztent megfelelő feltágulását, ezáltal appozícióját is. Mindezeken felül gátolja a gyógyszerbevonatú sztentek hatóanyag-leadását, valamint annak a célsejtekhez való eljutását.

Nehezíti a meszes plakkok megfelelő ellátását, hogy önmagában a fluoroszkópos kép alapján az esetek mintegy $50 \%$-ában [1] nehezen becsülhető a mészlerakódások jelenléte és mértéke, azok érfalon belüli elhelyezkedéséről pedig semmilyen információ nem nyerhető. Az érfali meszesedés karakterizálásának arany standard eljárása az intravascularis képalkotás, úgymint az optikaikoherencia-tomográfia (OCT) és az intravascularis ultrahangvizsgálat (IVUS) alkalmazása [2], ezek elérhetősége azonban - elsősorban magas költségük miatt - korlátozott. A koszorúerek kalciumtartalmának becslésére a költséghatékonysága miatt sokkal inkább elterjedt, CTvel noninvazívan mérhető Agatston- - vagy Ca- - score-t is használhatjuk [3]. Ennek segítségével a kalcium érlefutás szerinti elhelyezkedése mellett annak mennyisége is becsülhető.

A meszes plakkok által támasztott kihívások leküzdésére számos eljárást dolgoztak ki a klinikai gyakorlat számára [4], melyek közül itt csak a plakkmodifikációs lehetőségeket tekintjük át röviden. A bevezetésekor optimálisnak tartott rotációs atherectomia (rotablatio) a szúkületek mésztartalmának mennyiségét phagocytosisra alkalmas méretü (hozzávetóleg 5-10 um átmérójü) mikroszemcsék lemarásával csökkenti, ezzel könnyítve meg a sztentimplantációt. A jelenleg rendelkezésünkre álló, leginkább meghatározó, randomizált klinikai vizsgálat (ROTAXUS, [5]) eredményei alapján ugyanakkor 2 éves utánkövetés mellett nem volt szignifikáns különbség a meszes laesiókban rotablatiót követố vagy a nélkül elvégzett sztentimplantáció után a halálozásnak $(8,3 \%$ vs. $7,4 \%)$, a myocardialis infarctusnak $(8,3 \%$ vs. $6,5 \%)$ vagy az interveniált laesio ismételt revascularisatiójának $(13,8 \%$ vs. $16,7 \%)$ a tekintetében sem. A rotablatio Magyarországon jelenleg nem elérhető - alternatívája az orbitalis atherectomia: az ennek hatékonyságával kapcsolatban végzett randomizált vizsgálat (ORBIT II, [6]) eredményei alapján a major cardiovascularis adverz események (MCAE) és az interveniált laesio ismételt revascularisatiója szempontjából sem volt statisztikailag szignifikáns különbség az orbitalis és a rotációs atherectomia között. Mind a rotációs $[7,8]$, mind az orbitalis $[9,10]$ atherectomia esetén a vezetődrót lefutása mentén a plakkmodifikáció gyakran excentrikus, éppen a meszes plakk szerkezetét nem módosítja, amit vezetődrót okozta torzításnak nevezünk.

Hazánkban is elterjedt módszer a vágó- - „cutting” -, valamint a scoring ballonok alkalmazása, melyeket szintén elsősorban a meszes, hagyományos ballonokkal tör-
1. táblázat |AHA/ACC laesioklasszifikáció

\begin{tabular}{|c|c|c|}
\hline A & B & C \\
\hline Diszkrét $(<10 \mathrm{~mm})$ & Csőszerú (10-20 mm) & Diffúz \\
\hline Koncentrikus & Excentrikus & $\begin{array}{l}\text { Jelentősen tortuosus } \\
\text { proximalis szegmen- } \\
\text { tum }\end{array}$ \\
\hline Szöglettörés nélküli & $\begin{array}{l}\text { Mérsékelt szöglettö- } \\
\text { rés }\left(45-90^{\circ}\right)\end{array}$ & $\begin{array}{l}\text { Jelentős szöglettörés } \\
\left(>90^{\circ}\right)\end{array}$ \\
\hline Sima kontúrú & Irreguláris kontúrú & $\begin{array}{l}\text { Csak jelentős oldalág } \\
\text { elvesztése árán } \\
\text { tágítható }\end{array}$ \\
\hline $\begin{array}{l}\text { Nem vagy minimáli- } \\
\text { san meszes }\end{array}$ & $\begin{array}{l}\text { Közepesen vagy } \\
\text { súlyosan meszes }\end{array}$ & $\begin{array}{l}\text { Degenerált vénás } \\
\text { graft instabil laesióval }\end{array}$ \\
\hline $\begin{array}{l}\text { Teljes elzáródást nem } \\
\text { okozó }\end{array}$ & $\begin{array}{l}\text { Közepesen tortuosus } \\
\text { proximalis szegmen- } \\
\text { tum }\end{array}$ & \\
\hline Nem eredési helyzetú & $\begin{array}{l}\text { Eredési elhelyezke- } \\
\text { désü }\end{array}$ & \\
\hline Fő́gat nem érintő & Bifurcatiós laesio & \\
\hline $\begin{array}{l}\text { Thrombus jelenléte } \\
\text { nélkül }\end{array}$ & Thrombus jelenléte & \\
\hline
\end{tabular}

ACC $=$ Amerikai Kardiológiai Társaság; AHA = Amerikai Szívgyógyász Szövetség

2. táblázat | Releváns demográfiai, laesiós és intervenciós adatok

\begin{tabular}{lcccc}
\hline & 1. eset & 2. eset & 3. eset & 4. eset \\
\hline Életkor $($ év $)$ & 74 & 72 & 70 & 78 \\
\hline Nem & Férfi & Férfi & Férfi & Férfi \\
\hline Diabetes & Igen & Nem & Nem & Igen \\
\hline Perifériás érbetegség & Nem & Igen & Igen & Nem \\
\hline BMI $\left(\mathrm{kg} / \mathrm{m}^{2}\right)$ & 26,4 & 22,1 & 33,6 & 35,0 \\
\hline Agatston-score & 3706 & 3119 & 3388 & 7720 \\
\hline Kezelt ér & RCA & LAD & LAD & LAD \\
\hline Rotablatio & Igen & Nem & Nem & Igen \\
\hline Shockwave ballon & $3 \times 12$ & $3,5 \times 12$ & $3,5 \times 12$ & $2 \times 12$
\end{tabular}

$(\mathrm{mm} \times \mathrm{mm})$

\begin{tabular}{lcccc}
\hline $\begin{array}{l}\text { Shockwave-applikációk } \\
\text { száma }\end{array}$ & 80 & 80 & 80 & 80 \\
\hline Az alkalmazott sztent típusa & SES & SES & SES & SES \\
\hline Sztentméretek & $\begin{array}{c}3 \times 22, \\
3,5 \times 26, \\
(\mathrm{~mm} \times \mathrm{mm})\end{array}$ & $4 \times 18$ & $3 \times 22$, & $3 \times 30$ \\
& $3,5 \times 18$ & & & \\
\hline A beavatkozás hossza $($ perc $)$ & 92 & 39 & 56 & 63 \\
\hline
\end{tabular}

$\mathrm{BMI}=$ testtömegindex; $\mathrm{LAD}=\mathrm{a}$ bal coronaria elülső leszálló ága; RCA = jobb koszorúér; SES = szirolimuszkibocsátó sztent

ténő dilatációnak ellenálló laesiók kezelésére fejlesztettek ki. A cutting ballonnal nagyobb akut lumennövekedés érhetô el, mint a hagyományos, non-compliant (NC) ballonok alkalmazásával $[11,12], 6$ hónap elteltével azonban a restenosisráta $(31 \%$ vs. $30 \%)$ nem tért el a két eljárás esetén, míg a perforációk aránya szignifikánsan magasabb volt a cutting ballonnal kezelt erekben [13]. 
A scoring ballonok hatékonyságának tekintetében nem áll rendelkezésre randomizált vizsgálati eredmény.

Mindezek alapján a rendkívül, sokszor körkörösen meszes, B- vagy C-típusú laesiók (1. táblázat) ellátása minden hagyományos eszköz felhasználása mellett is sikertelen maradhat. Az ezen laesiók támasztotta kihívás megoldásához szolgálhat segítségül egy, a coronariaintervenciók esetében meróben új eljárás, melyet a nemzetközi szakirodalom intravascularis coronaria-lithoplastica (IVL) néven említ [14]. A Disrupt-tanulmányban (Shockwave Coronary Rx Lithoplasty Study; NCT02650128; [15]) alkalmazott Shockwave Medical (Santa Clara, CA, USA) IVL-ballon múködésének lényege, hogy a mindössze 4 atm nyomásra felfújt ballonban elektromos impulzussal létrehozott, másodpercenként leadott circumferentialis lökéshullámokkal repedéseket hozunk létre a kalcifikált plakkban, mely aztán hagyományos ballonos technikával már megfelelően tágítható, és a laesio sztenttel fedhető [16]. Az eljárás legnagyobb előnye, hogy az impulzusokban érkező, akár 50 atm nyomást elérő, de kis amplitúdójú mechanikai hullámok az érfal ép részeit nem teszik ki a hagyományos ballonok használatakor jelentkező barotraumának. Mindehhez igen magas klinikai sikerarány (95\%-ban 50\%-nál kisebb residualis szúkület [15]) társul.

Klinikánkon ezen ígéretes eredmények ismeretében 4 beteg komplex, igen meszes laesiójának intervenciójához alkalmaztuk a technikát a közelmúltban.

\section{Esetek}

A betegek releváns demográfiai paraméterei, a kezelt koszorúérnek és az alkalmazott sztenteknek a tulajdonságai a 2. táblázatban láthatók. Betegeink 70-78 éves férfiak voltak, akiknél diabetes mellitus vagy kiterjedt perifériás veróérbetegség is társult a klinikai képet vezető anginás panaszokhoz. Többségükben lezajlott infarctus vagy korábbi coronariaintervenció is szerepelt az előzményi adatok között. A betegek valamennyi koszorúérre összesített Agatston-score-értéke minden esetben meghaladta a 3000-et.

$\mathrm{Az}$ 1. ábrán a kezelt érszakaszok CT-angiográfiás és angiográfiás felvételeit mutatjuk be az intervenciót meg-
CT
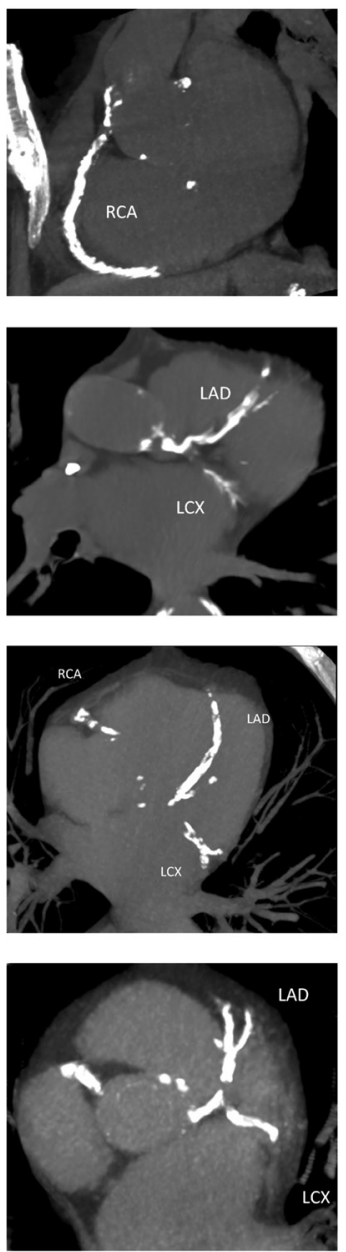

Angio előtte
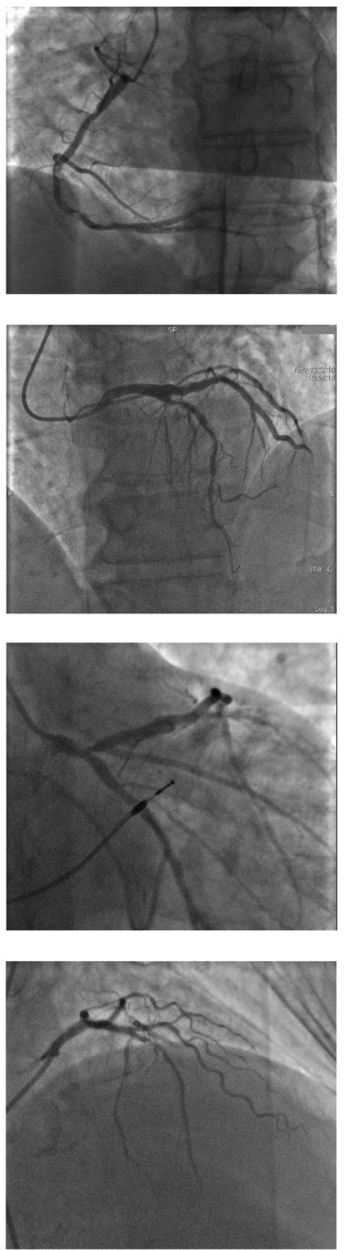

Angio utána
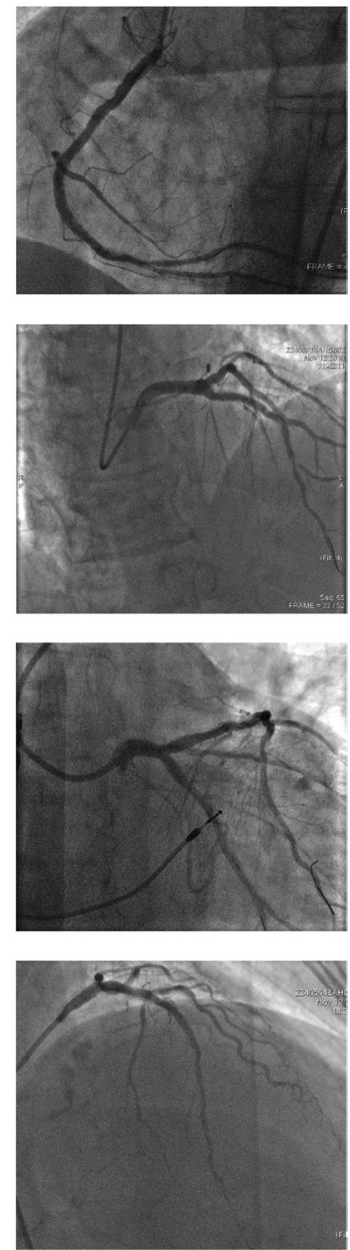

1. ábra

A betegek CT- és invazív angiográfiás felvételei

CT = számítógépes tomográfia; LCX = bal körbefutó coronariaág; LAD = a bal coronaria elülső leszálló ága; RCA = jobb koszorúér 

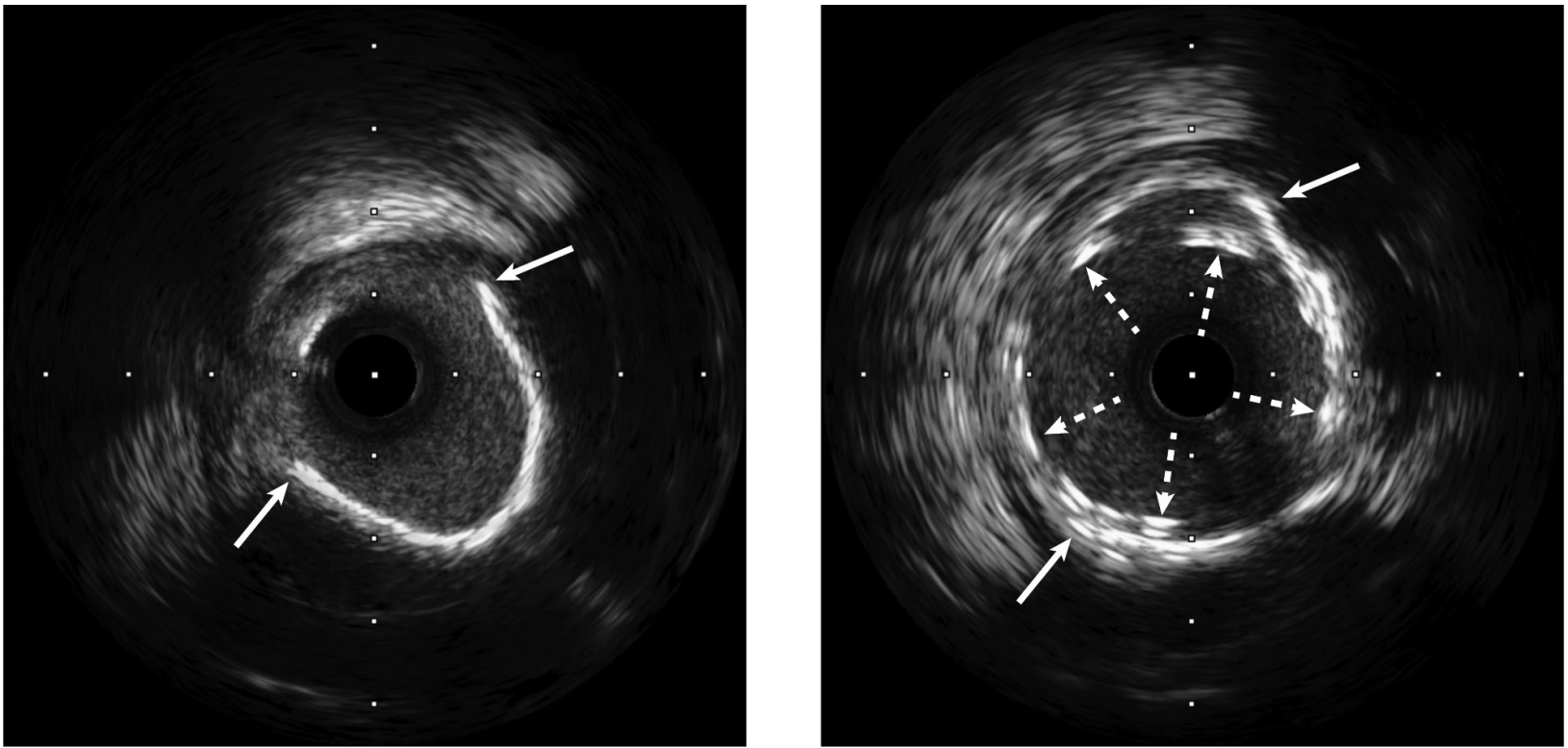

2. ábra

IVUS-felvételek intervenció előtt és után. A fehér nyilak a mészlerakódás széleit jelölik, a szaggatott nyilak pedig a deponált sztent rácsait

IVUS = intravascularis ultrahangvizsgálat

előzően, majd azt követően. Két beteg esetén a laesiók mésztartalma és a lumenszúkület foka miatti eszközlevezetési nehézség folytán rotációs atherectomiát is igénybe kellett venni a szúkületek ballonos dilatációja előtt, a körkörös meszesedés IVL-ballon nélkül azonban ennek ellenére is tágíthatatlan maradt mindkét esetben. A Shockwave ballon segítségével ugyanakkor a calcificatio feltördelését effektíven lehetett kivitelezni, majd az így preparált laesiókban a sztentek deponálását akadály nélkül lehetett elvégezni. A 2. ábrán IVUS-felvételeket mutatunk be 1-1 intervenció előtti, majd utáni helyzetben. Valamennyi betegünkben kielégítő angiográfiás eredményt kaptunk, residualis szúkület a kezelt szakaszok egyikén sem volt kimutatható.

\section{Következtetés}

$\mathrm{Az}$ új, intravascularis coronaria-lithoplastica segítségével valamennyi betegünk esetében jó angiológiai eredményt értünk el olyan laesiókban, melyek a módszer alkalmazása nélkül percutan revascularisatióra alkalmatlanok lennének. Összességében tehát az intravascularis coronaria-lithoplastica ígéretes, új intervenciós lehetőség a masszívan meszes laesiók ellátására. Megjegyzendő, hogy a jövőben - megfelelő indikációs körben - a perifériás intervenciók során tapasztalt hasonló nehézségek megoldásában is jelentős segítséget jelenthet az eljárás.

Anyagi támogatás: A közlemény megírása anyagi támogatásban nem részesült.

Szerzői munkamegosztás: N. B. T.: A kézirat és az ábraanyag elkészítése, szerkesztése. É. I. F., Sz. B., N. F.:
Az ábraanyag és a kézirat szerkesztése. B. D., M. B.: A kézirat szerkesztése. A cikk végleges változatát valamennyi szerző elolvasta és jóváhagyta.

Érdekeltségek: A szerzőknek a jelen közleményben foglalt eszközökkel, eljárásokkal kapcsolatosan nincsenek érdekeltségeik.

\section{Irodalom}

[1] Mintz GS, Popma JJ, Pichard AD, et al. Patterns of calcification in coronary artery disease. A statistical analysis of intravascular ultrasound and coronary angiography in 1155 lesions. Circulation 1995; 91: 1959-1965.

[2] Zeng Y, Tateishi H, Cavalcante R, et al. Serial assessment of tissue precursors and progression of coronary calcification analyzed by fusion of IVUS and OCT: 5 -year follow-up of scaffolded and nonscaffolded arteries. JACC Cardiovasc Imaging 2017; 10: 1151-1161.

[3] Agatston AS, Janowitz WR, Hildner FJ, et al. Quantification of coronary artery calcium using ultrafast computed tomography. J Am Coll Cardiol. 1990; 15: 827-832.

[4] Kassimis G, Raina T, Kontogiannis N, et al. How should we treat heavily calcified coronary artery disease in contemporary practice? From atherectomy to intravascular lithotripsy. Cardiovasc Revasc Med. 2019; 20: 1172-1183.

[5] de Waha S, Allali A, Büttner HJ, et al. Rotational atherectomy before paclitaxel-eluting stent implantation in complex calcified coronary lesions: two-year clinical outcome of the randomized ROTAXUS trial. Catheter Cardiovase Interv. 2016; 87: 691700 .

[6] Généreux P, Bettinger N, Redfors B, et al. Two-year outcomes after treatment of severely calcified coronary lesions with the orbital atherectomy system and the impact of stent types: insight from the ORBIT II trial. Catheter Cardiovasc Interv. 2016; 88: 369-377.

[7] Attizzani GF, Patrício L, Bezerra HG. Optical coherence tomography assessment of calcified plaque modification after rotational atherectomy. Catheter Cardiovasc Interv. 2013; 81: 558-561. 


\section{ESETISMERTETÉS}

[8] Mestre RT, Alegria-Barrero E, Di Mario C. A coronary 'tunnel': optical coherence tomography assessment after rotational atherectomy. Catheter Cardiovasc Interv. 2014; 83: E171-E173.

[9] Karimi Galougahi K, Shlofmitz RA, Ben-Yehuda O, et al. Guiding light: insights into atherectomy by optical coherence tomography. JACC Cardiovasc Interv. 2016; 9: 2362-2363.

[10] Sotomi Y, Cavalcante R, Shlofmitz RA, et al. Quantification by optical coherence tomography imaging of the ablation volume obtained with the orbital atherectomy system in calcified coronary lesions. EuroIntervention 2016; 12: 1126-1134.

[11] Kurbaan AS, Kelly PA, Sigwart U. Cutting balloon angioplasty and stenting for aorto-ostial lesions. Heart 1997; 77: 350-352.

[12] Okura H, Hayase M, Shimodozono S, et al. Mechanisms of acute lumen gain following cutting balloon angioplasty in calcified and noncalcified lesions: an intravascular ultrasound study. Catheter Cardiovasc Interv. 2002; 57: 429-436.

[13] Mauri L, Bonan R, Weiner BH, et al. Cutting balloon angioplasty for the prevention of restenosis: results of the Cutting Bal- loon Global Randomized Trial. Am J Cardiol. 2002; 90: 10791083.

[14] Tovar Forero MN, Wilschut J, Van Mieghem NM, et al. Coronary lithoplasty: a novel treatment for stent underexpansion. Eur Heart J. 2019; 40: 221.

[15] Brinton TJ, Ali AZ, Hill JM, et al. Feasibility of Shockwave coronary intravascular lithotripsy for the treatment of calcified coronary stenoses. Circulation 2019; 139: 834-836.

[16] De Silva K, Roy J, Webb I, et al. A calcific, undilatable stenosis: lithoplasty, a new tool in the box? JACC Cardiovasc Interv. 2017; 10: 304-306.

(Németh Balázs Tamás dr., Budapest, Városmajor u. 68., 1122 e-mail: nemeth.balazs_tamas@med.semmelweis-univ.hu)

\section{"Bene cogitata si excidunt non occidunt." (Ha feleded is, a jó gondolat megmarad.)}

A cikk a Creative Commons Attribution 4.0 International License (https://creativecommons.org/licenses/by/4.0/) feltételei szerint publikált Open Access közlemény, melynek szellemében a cikk bármilyen médiumban szabadon felhasználható, megosztható és újraközölhetö, feltéve, hogy az eredeti szerző és a közlés helye, illetve a CC License linkje és az esetlegesen végrehajtott módositások feltüntetésre kerülnek. (SID_1) 